\title{
QUALITATIVE AND QUANTITATIVE IDENTIFICATION OF PAH IN THE BOTTOM SEDIMENTS OF MOSCOW URBAN RIVERS
}

\author{
D. KRAMER \& I. TIKHONOVA \\ Faculty of Biotechnology and Industrial Ecology, Mendeleev University of Chemical Technology of \\ Russia, Russian Federation.
}

\begin{abstract}
Qualitative and quantitative identification of polycyclic aromatic hydrocarbons (PAHs) in bottom sediments of Moscow urban rivers with different levels of anthropogenic impact was made, the content of PAH was measured and a comparison between PAH content in Moscow urban rivers and other environmental objects was carried out. The results of our observation showed that bottom sediments of Moscow contain PAHs such as anthracene, fluoranthene, benzo(a)pyrene and others with the composition of PAH being the same for different rivers. Fluoranthene and benzo(b)fluoranthene have the highest concentrations and rivers Tarakanovka and Nischcenka are the most polluted rivers with the latest having PAH containment over $28 \mathrm{mg} / \mathrm{kg}$ in sample point no. 4. River Los is the cleanest river and has the same PAH concentrations as background territories have. Keywords: Moscow urban rivers, bottom sediments, PAH identification.
\end{abstract}

\section{INTRODUCTION}

On Moscow urban territory, there are 141 small rivers and streams together with 430 ponds. The largest of them are rivers Yauza, Shodnya and Setun, which begin in Moscow region and are tributaries to Moscow River. The existing drainage system in the city is functionally used in the removal and treatment of surface runoff. Water bodies, partially deformed by technical means, together with the city's drainage network form a single collector and river network. The quality of water in the small rivers of Moscow is formed on the entire watershed and is influenced by the economic activity of the city and partly of the Moscow region.

Bottom sediments of surface watercourses are traditionally used as an indicator for the detection of composition, intensity and scale of industrial pollution. This is due to the fact that the channel deposits are the final link in the local landscape interfaces, which makes their composition reflect the geochemistry of the catchment areas. This dependence manifests vividly in the basins of the urbanized areas, where most of the streams are the main receivers of sewage and are polluted by industrial fallout, waste and melioration runoff from the developed areas. This leads to a fundamental change in the ecological status of watercourses.

Technological silts are the bulk of water system pollutants [1]. Among the many toxic pollutants in rivers, polycyclic aromatic hydrocarbons (PAHs) occupy a special place. These compounds are considered as super first-class danger ecotoxicants because many of them have mutagenic, carcinogenic and teratogenic properties and have the ability to accumulate in environmental objects. PAHs are a group of dozen substances that have two or more benzene rings in their structure [2].

Being widely distributed in the environment, PAHs are included in the list of priority pollutants by both the European Community (EC) and the U.S. Environmental Protection Agency (EPA). It is considered that mainly 16 compounds included in this group must be determined in drinking, surface and waste water [3]. In Russia, nowadays only one compound belonging to this class is a subject to mandatory control - benzo(a)pyrene [4]. It is clear that over time, the list of controlled compounds will expand closer to international practice. 
In this paper, a qualitative and quantitative determination of PAHs in sediments of several urban rivers of Moscow with different anthropogenic impacts was conducted. The names of studied rivers are Los, Kotlovka, Businka, Tarakanovka and Nischcenka.

\section{METHODOLOGY AND FIELD OBSERVATIONS}

\subsection{Field observations}

First part of the work was to observe the visual condition of rivers with photographing the area. Our goal was to make the description of the coast, vegetation description and to identify possible sources of pollutants in the rivers.

\subsubsection{The river Los description}

River Los flows in the northeast of Moscow and is the left and the largest tributary of the river Ichka. Its length is $4.5 \mathrm{~km}$ and the catchment area is about $8 \mathrm{~km}^{2}$. River Los is the largest pure natural water flowing in Moscow; river basin is almost completely forested and does not intersect with highways. River Los and its tributaries flow entirely within the National Park 'Losinyi Ostrov' (Moose Island). Among the pure streams of Moscow, River Los has the largest average annual water consumption (due to spring floods). However, it must be noted that the average consumption of water is strongly overflowing in spring, and in summer Los dries almost to the mouth. River Los basin does not contain any commercial, industrial or residential areas.

\subsubsection{The river Kotlovka description}

River Kotlovka flows in the south of Moscow, is the third largest right tributary of the Moskva River and originates in Bitza forest park. The upper reaches of the river enclosed in storm water sewers. Then, it flows in an open channel, flowing in the collector only in a small area in the middle reaches. The general direction of the flow of the river is in the north-east direction. The total length of the river is $7.6 \mathrm{~km}, 4.7 \mathrm{~km}$ of which is in the open channel and $2.9 \mathrm{~km}$ in the sewers. Average water flow is $0.14 \mathrm{~m}^{3} / \mathrm{s}$. The ecological condition of the river Kotlovka improved after the series of measures in 2009. A part of the flow of the river is almost completely built up, and another part flows in the places of scenic and forested valley, which in 1991 declared as a natural monument. According to the data of the year 2012, water quality in river Kotlovka is estimated as 'conditionally clean' [5].

\subsubsection{The river Businka description}

River Businka is situated in the north of Moscow and Moscow region. The total length of the river is about $4.5 \mathrm{~km}, 1.4 \mathrm{~km}$ of which flows in Moscow (part of the river lies in the collector). It is a right tributary to river Likhoborka, which in turn flows into the river Yauza. The river originates in the Moscow region in the northern section of the cemetery of Dolgoprudny town or (in the form of troughs of spring runoff) just west of it, and then crosses the Moscow Ring Road in the area of Korovinskoe highway, and flows up to the junction with Likhoborskiy bypass channel. Except for short open areas in Korovino and Businovo, river flows in the underground collector. River Businka is almost entirely contaminated. It takes the discharges from snow melting point, heating station, illegal dumps and several industrial objects.

\subsubsection{The river Tarakanovka description}

River Tarakanovka flows in the west of Moscow and is a left tributary of the Moskva River. Its total length is $7.8 \mathrm{~km}$ (a large part lies in the collector). Basin area is $18.3 \mathrm{~km}^{2}$. In the 1950-1960s of 20th century, the river was almost completely removed to the collector. Small open areas of the river 
remained near Horoshevskoe and Zvenigorodskoe highways and Leningradsky Prospect. In recent years, river Tarakanovka is considered to be one of the most polluted rivers in Moscow. The water at the mouth of the river is estimated as 'contaminated' according to its quality [5]. In the first half of year 2013, high concentrations of organic compounds and iron were found in its estuary [6]. Therefore, Tarakanovka flows into the Moscow River not directly, but passes through a pre-treatment facility 'Tarakanovskiy'.

\subsubsection{The river Nischenka description}

River Nischcenka is situated in the southeast of Moscow and is a left tributary of the Moskva river. The river is about $11-\mathrm{km}$ long (partially enclosed in a collector). The basin area is $85.7 \mathrm{~km}^{2}$. Nischcenka has the largest number of tributaries than all other small Moscow rivers; the main ones being river Ponomarka, river Kolomenka (left tributaries) and river Khokhlovka (right tributary). The river is used for rafting Pauper snow that is removed from the surrounding areas. Nischenka flows in the industrial zone and takes discharges from several facilities. According to the data of 2008, river Nischcenka is considered the most polluted river in Moscow [7]. Though in 2012 water quality improved to ‘conditionally clean' [5].

\subsection{Sampling operations}

On the basis of the results of our field observation, 9 profiles (sampling points) on rivers Los, Businka, Tarakanovka and Nischcenka and 11 profiles on river Kotlovka were chosen. Sampling was carried out during spring flood for rivers Businka and Tarakanovka and during autumn flood for all five rivers. Sampling was carried out from rivers' sources to confluence points to other rivers. Bottom sediment sample was taken from the upper layer $(0-5 \mathrm{~cm})$. All samples were air-dried and filtered through a $0.1-\mathrm{mm}$ sieve.

\subsection{Analyzing procedures}

The analytical procedure for determining PAH concentrations in bottom sediments was as follows: $10 \mathrm{~g}$ of sediment sample was dissolved in $50 \mathrm{ml}$ of methylene chloride $\left(\mathrm{CH}_{2} \mathrm{Cl}_{2}\right)$. Extraction process was carried out in ultrasonic bath for $15 \mathrm{~min}$. The extract was then filtered in a chemical glass and solvent was puffed by air flow from special gravimetrical beaker. Then, the precipitate was again dissolved in methylene chloride and the solution was transferred to a 12-ml vial. After that, the solution was transferred to a glass filled with waterless sodium sulfate, which was then poured on the top of an 18-mm column filled with activated silica gel and consequently eluted by three eluents. Elution scheme is shown in Fig. 1.

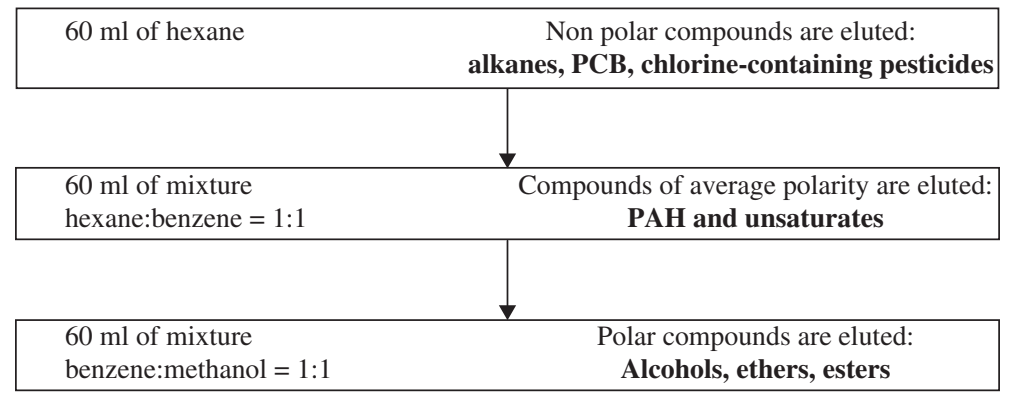

Figure 1: Elution scheme (sample preparation for IR spectrometry, HPLC and GC-MS). 
The eluates received were concentrated on rotary evaporator and then transferred to a $12-\mathrm{ml}$ vial. PAH identification was carried out on HPLC 'Stayer' with fluorimetric detection and C-18 silica gel column Luma $3 \mathrm{u} \mathrm{C}-18,3 \mu \mathrm{m}, 150 \times 3.0 \mathrm{~mm}$. A mixture of acetonitrile and water was used as eluent.

\section{RESULTS AND DISCUSSION}

\subsection{Qualitative PAH identification}

Qualitative PAH identification was carried out in two stages.

On the first stage (preliminary identification), chromatograms for several PAH standards using mixture of acetonitrile/water $=80: 20$ were obtained. Transcription of these chromatograms was done according to the relative retention times of PAH (to anthracene) and to literature data [3]. In Fig. 2, the chromatogram of sample Los 2, hexane/benzene fraction, can be seen. Transcription of this chromatogram is presented in Table 1.

However, the identification of PAH based only on retention time coincidence can be wrong and can provide ambiguous results. It is important to check if the separated peaks respond only to one compound. Therefore, on the second stage of qualitative PAH method of additive standards was used to confirm our preliminary identification. The volume and concentration of additives were selected in such a way that significant peak increase on chromatogram can be seen and the nearby peaks were not masked by this increase.

A mixture of acetonitrile and water in the ratio of 75:25 was used as an eluent, which provided a better separation of the analytes. As the ratio of compounds in the eluent changed, new chromatograms for PAH standards were done. Four of 16 PAHs were out of consideration:

(1) Naphthalene, which is volatilized during sample preparation.

(2) Acenaphthene (cannot be detected on this wavelength).

(3) Acenaphthylene (cannot be detected on this wavelength).

(4) Indeno(1,2,3-cd)pyrene (no standard).

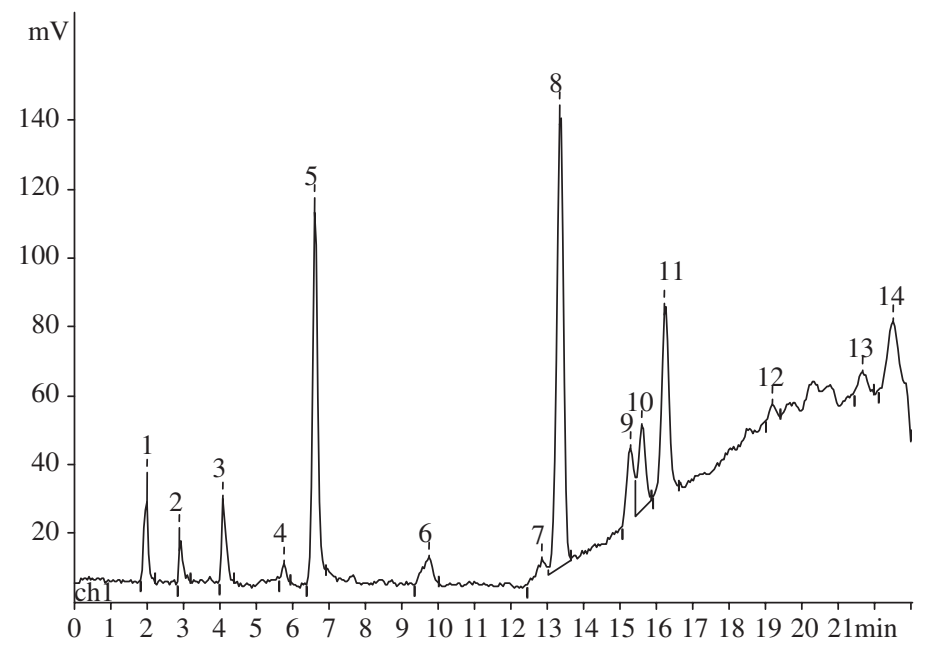

Figure 2: Chromatogram of bottom sediment sample Los 2. Fraction: a mixture of hexane and benzene (1:1). Eluent: a mixture of acetonitrile and water (80:20). 
Table 1: Transcription of chromatograms of sample Los 2; fraction: a mixture of hexane and benzene $(1: 1)$.

\begin{tabular}{lccc}
\hline PAH & Peak no. & Retention time $(\mathrm{min})$ & Peak area $\left(\mathrm{mV}^{*} \mathrm{sec}\right)$ \\
\hline Fluorene & 5 & 6.606 & 1064.46 \\
Fluoranthene & 6 & 9.731 & 172.03 \\
Benzo(a)anthracene & 7 & 12.84 & 109.05 \\
Chrysene & 8 & 13.34 & 1724.04 \\
Benzo(b)fluoranthene & 9 & 15.26 & 293.79 \\
Benzo(k)fluoranthene & 10 & 15.58 & 339.70 \\
Benzo(a)pyrene & 11 & 16.21 & 776.34 \\
Dibenz(a,h)anthracene & 12 & 19.17 & 62.29 \\
Indeno(1,2,3-cd)pyrene & 13 & 21.64 & 116.61 \\
\hline
\end{tabular}

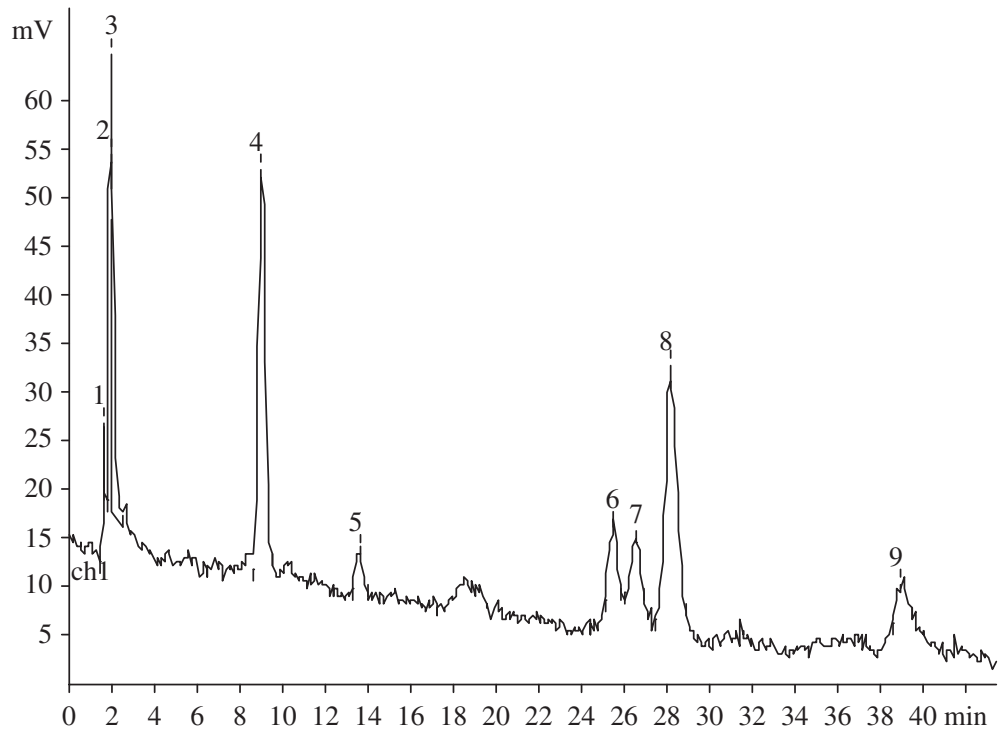

Figure 3: Chromatograms of bottom sediment sample Los 2 without additions. Fraction: a mixture of hexane and benzene (1:1). Eluent: a mixture of acetonitrile and water in the ratio of 75:25.

Fluorene peak does not occur even when spiked at very high concentrations. Since it is not confirmed with a spiked standard, it should be some other substance. US EPA 8310 is the widely used method for determining PAHs such as naphthalene, acenaphthylene, acenaphthene and fluorine with a UV detector, which we did not have. To conduct our analysis, all eluates were transferred to acetonitrile.

In Figs 3 and 4, the chromatograms of sample Los 2, a fraction of hexane:benzene, without additions can be seen (Fig. 3) and with additions of fluoranthene, benzo(b)fluoranthene, benzo(k) 
fluoranthene and also benzo(g,h,i)perylene (Fig. 4). In Table 2, the transcription of these chromatograms is presented.

As can be seen from these data in sample Los 2, a fraction of hexane:benzene, the presence of all PAHs of interest was confirmed.

Qualitative PAH analysis resulted in the identification of several PAHs: anthracene, fluoranthene, benzo(b)fluoranthene, benzo(k)fluoranthene, benzo(g,h,i)perylene, pyrene and benzo(a)pyrene. Pyrene was identified only in rivers Tarakanovka and Nischcenka, which were considered to have the biggest anthropogenic impact among studied rivers. Identification of benzo(a)anthracene and chrysene is controversial due to the small difference in the retention times of these substances. Identification of dibenz(a,h)anthracene and phenanthrene did not confirm in any sample. This may be

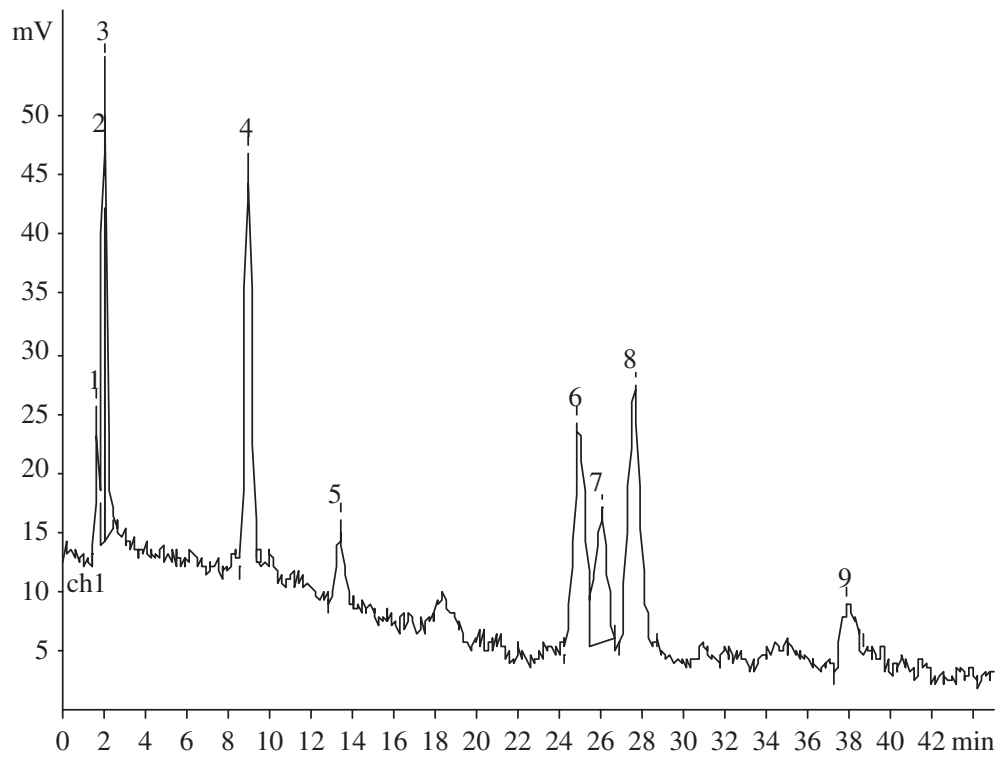

Figure 4: Chromatograms of bottom sediment sample Los 2 with additions. Fraction: a mixture of hexane and benzene (1:1). Eluent: a mixture of acetonitrile and water (75:25).

Table 2: Transcription of chromatograms of sample Los 2; fraction: a mixture of hexane and benzene $(1: 1)$.

\begin{tabular}{|c|c|c|c|c|c|c|}
\hline \multirow[b]{2}{*}{ PAH } & \multicolumn{3}{|c|}{ Without addition } & \multicolumn{3}{|c|}{ With addition } \\
\hline & Peak no. & $\mathrm{Rt}(\min )$ & $\mathrm{S}(\mathrm{mV} * \mathrm{sec})$ & Peak no. & $\mathrm{Rt}(\min )$ & $\mathrm{S}(\mathrm{mV} * \mathrm{sec})$ \\
\hline Fluorene & 4 & 9.047 & 939.04 & 4 & 8.965 & 773.03 \\
\hline Fluoranthene & 5 & 13.61 & 114.89 & 5 & 13.40 & 169.57 \\
\hline Benzo(b)fluoranthene & 6 & 15.26 & 222.70 & 6 & 24.96 & 711.81 \\
\hline Benzo(k)fluoranthene & 7 & 15.58 & 172.43 & 7 & 26.06 & 431.62 \\
\hline Benzo(a)pyrene & 8 & 16.21 & 972.44 & 8 & 27.63 & 855.12 \\
\hline $\operatorname{Benzo}(g, h, i)$ perylene & 9 & 39.03 & 129.39 & 9 & 37.96 & 219.83 \\
\hline
\end{tabular}

PAH standards are in bold. 
Table 3: The composition of PAH in bottom sediments of different rivers.

\begin{tabular}{lccccc}
\hline Identified PAH & Los & Kotlovka & Tarakanovka & Businka & Nischcenka \\
\hline Anthracene & + & + & + & + & + \\
Fluoranthene & + & + & + & + & + \\
Pyrene & - & - & + & - & + \\
Benzo(a)anthracene & + & + & + & + & + \\
Benzo(b)fluoranthene & + & + & + & + & + \\
Benzo(k)fluoranthene & + & + & + & + & + \\
Benzo(a)pyrene & + & + & + & + & + \\
Benzo(g,h,i)perylene & + & + & + & + & + \\
\hline
\end{tabular}

Remark: +, substance identified; - , substance not identified.

due to a weak signal of the substances and thus complexity in selecting a proper concentration for additions.

The composition of PAH in bottom sediments of different rivers is presented in Table 3.

\subsection{Quantitative PAH identification}

Quantitative HPLC analysis is based on the fact that the height of the peak and its area on chromatogram are proportional to the amount of the substance present in the sample. Based on this, it is possible to calculate the concentration of PAHs in our selected sediment samples by using calibration method. To achieve this, six identified priority PAHs were chosen, based on our qualitative analysis: anthracene, fluoranthene, benzo(b)fluoranthene, benzo(k)fluoranthene, benzo(k)pyrene and benzo(g,h,i)perylene.

For each of the chosen PAH, a calibration curve was built. Based on these calibration curves, the concentrations of the considered PAH in 10 samples (two sampling points on each river) of bottom sediments were calculated. The sum of PAH concentrations for each sample was also calculated and the results were compared with those of other objects of the environment. The results are presented in Table 4.

The table shows that fluoranthene, benzo(b)fluoranthene and benzo(g,h,i)perylene are the dominating PAHs in bottom sediments of Moscow urban rivers. A similar situation is observed in the soils of Moscow parks, as well as in the sediments of Svalbard. In river Los, only the concentration of benzo(g,h,i)perylene exceeds EAC in sediment, whereas in rivers Tarakanovka and Nischcenka every observed PAH exceeds that mark, sometimes more than 66 times (benzo(g,h,i)perylene in sampling point 8 of river Nischcenka). Rivers Kotlovka and Businka also have considerable exceeds for several PAH. In Fig. 5, the sum of PAH concentrations in every sample of bottom sediments can be seen.

From this figure, it can be seen that the sum of PAH concentrations in bottom sediments of river Nischcenka is several times higher than in other rivers. The lowest PAH concentration occurs in river Los, which flows in national park 'Losinii Ostrov' (Moose Island) and has minimal anthropogenic impact. It should be noted that the concentrations of PAHs in the Los River coincide with the concentrations of PAHs in the soils of Moscow parks, which are the background areas.

A comparison of our results with those of other observations of PAH concentrations in rivers of different regions is presented in Fig. 6. 


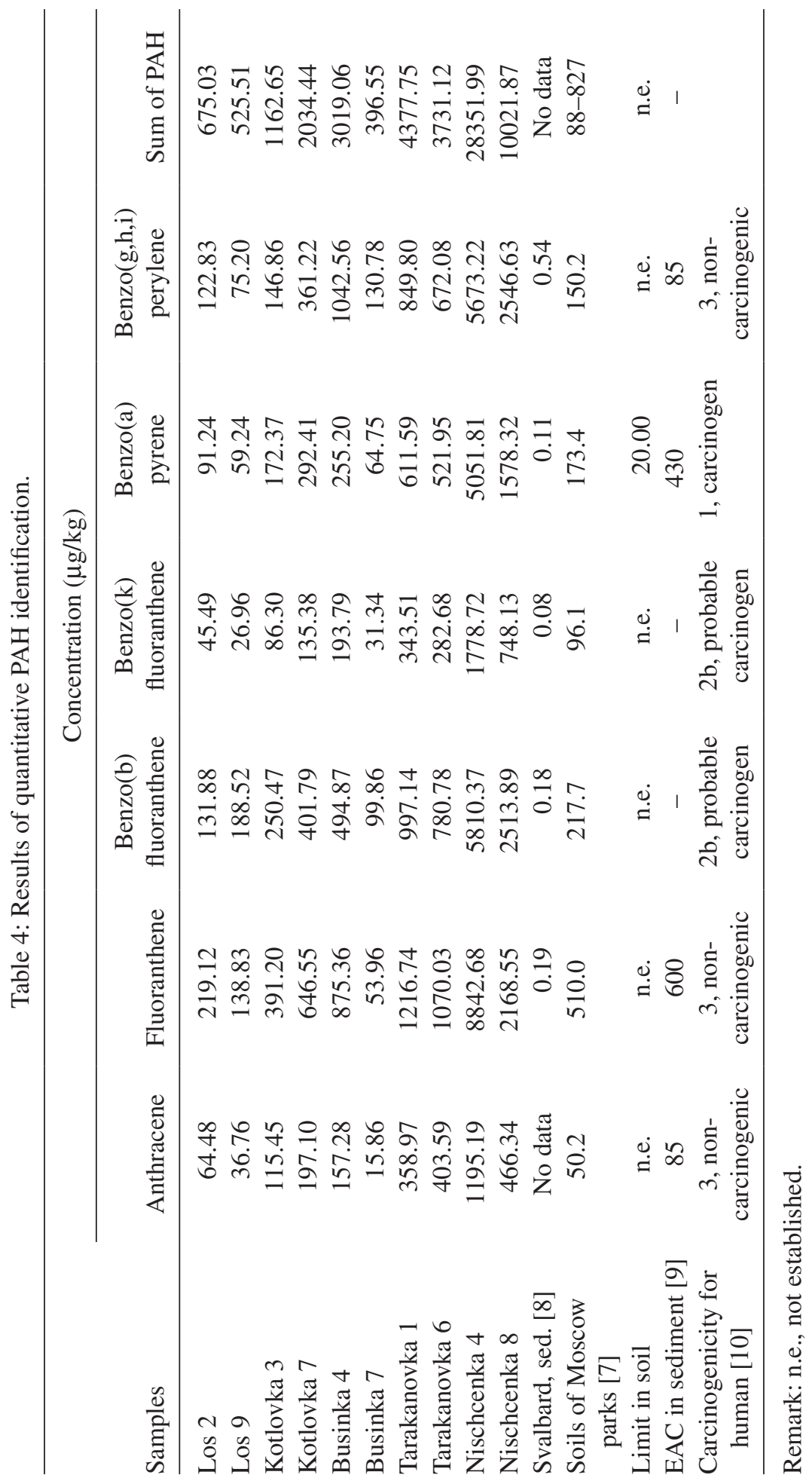




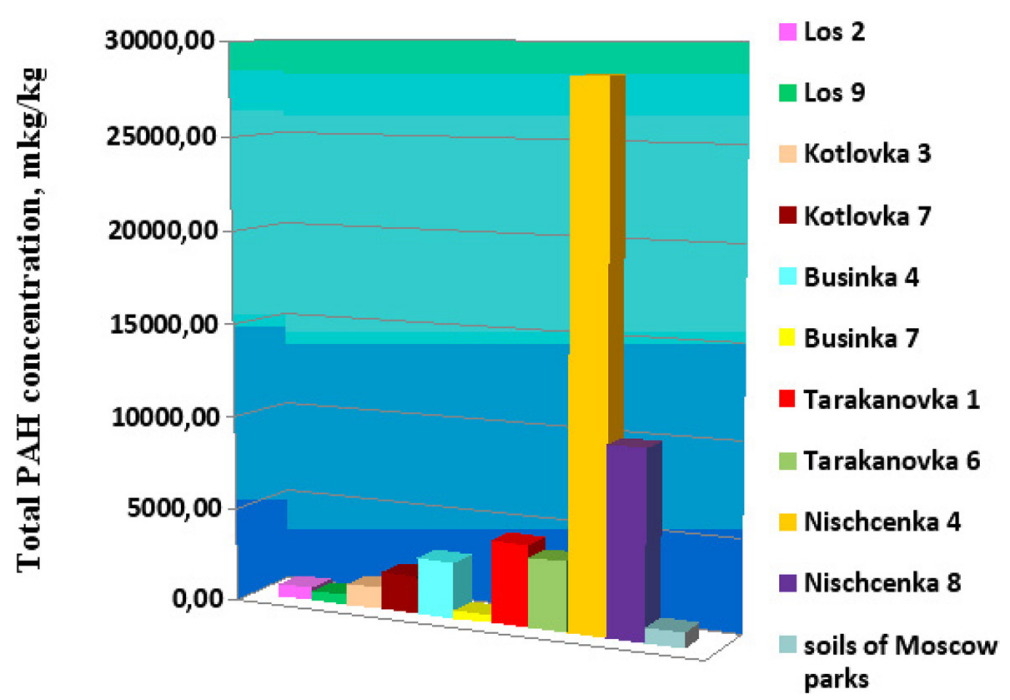

Figure 5: The sum of PAH concentrations in bottom sediments' samples.

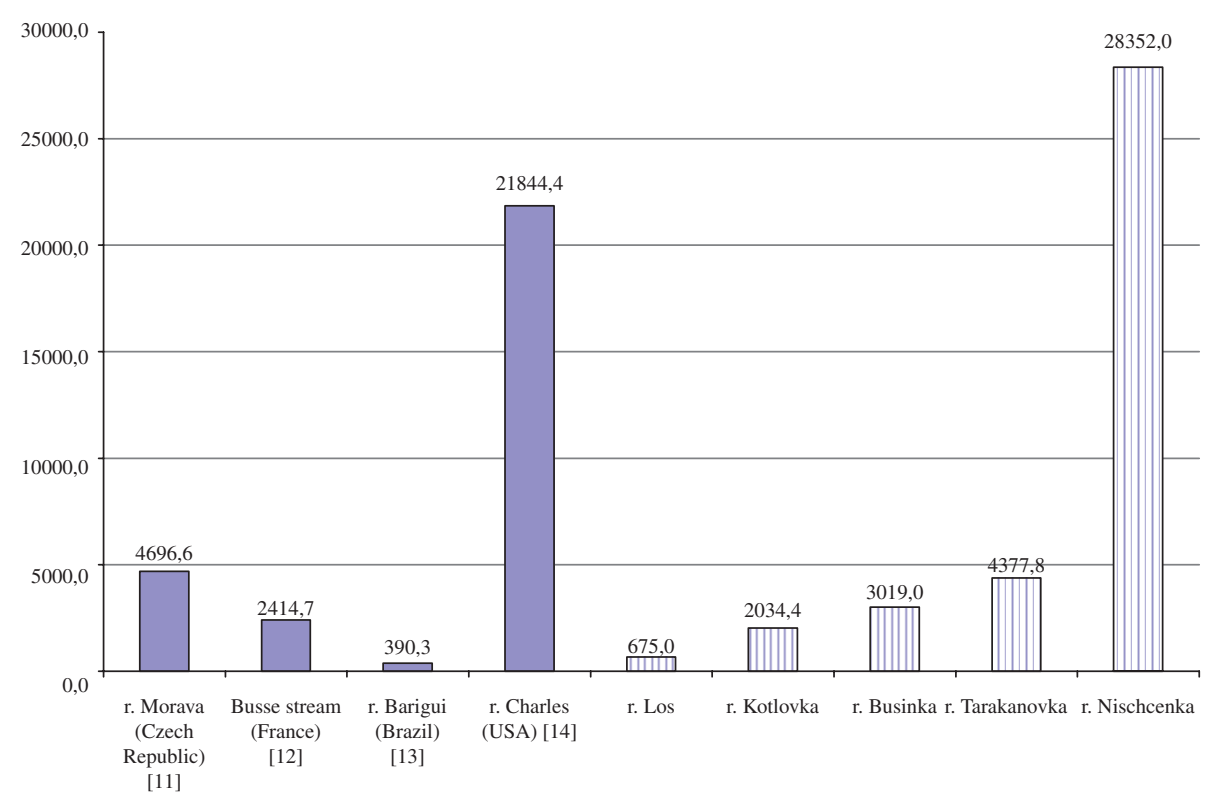

Figure 6: The sum of PAH concentration in the rivers of different regions.

From these data, it can be seen that the level of PAH contamination in Moscow small rivers is comparable with those of rivers from other regions. For example, rivers Morava and Charles have huge industrial pressure just like rivers Tarakanovka and Nischcenka. Rivers Los and Barigui are situated in urban area but without huge anthropogenic impact. 


\section{CONCLUSIONS}

The qualitative and quantitative identification of PAHs in the sediments of small rivers in Moscow with various anthropogenic impact was carried out. As a result of qualitative analysis, the following PAHs were identified: anthracene, fluoranthene, benzo(a)anthracene, benzo(b)fluoranthene, benzo(k) fluoranthene, benzo(g,h,i)perylene, pyrene and benzo(a)pyrene. The list of PAHs found in different rivers is the same.

The results of quantitative analysis showed that the sediments of small rivers are heavily polluted by PAHs. The highest concentrations were observed for fluoranthene, benzo(b)fluoranthene and benzo(g, h, i)perylene. The maximum concentrations of PAHs were found in the sediments of rivers Tarakanovka and Nischchenka, which have the biggest anthropogenic pressure.

This is the first step in the work of analyzing PAH pollution in Moscow small rivers. In future efforts, we plan to enlarge a number of rivers observed and also analyze all 16 priority PAHs in these rivers. Based on these results, we plan to develop a map of PAH distribution in bottom sediments of Moscow rivers in the future.

\section{REFERENCES}

[1] Kramer, D., Mulyashov, S. \& Tichonova, I., Identification of organic compounds in the bottom sediments of Moscow urban rivers. WIT Transactions on Ecology and the Environment, Vol. 172, WIT Press: Southampton, 2013, ISSN online 1743-3541, ISSN print 1746-448X.

[2] Ulahovich, N.A., Kutireva, M.P., Medyantseva, E.P. \& Babkina, S.S., Ecotoksikanti. Uchebnoe posobie dlya lektsionnogo kursa "Chimiya v elologii" (Ecotoxicants. Tutorial for lecture course "Chemistry in Ecology"), Kazan State University publishing, 2010.

[3] Soniassy, R., Sandra, P. \& Schlett, C., Water Analyzes: Organic Micropollutants, HewlettPackard Company, Waldbronn, Germany, 1994.

[4] GN 2.1.72041-06. Predelno-dopustimye concentracii (PDC) chimicheskich veschcestv v pochve: gigienicheskie normativy (Hygienic norms GN 2.1.7.2041-06 "Limit allowable concentrations (LAC) of substances in soil"), M., Federal Centre of Hygiene and Epidemiology of Rospotrebnadzor, 2006.

[5] Doklad o sostoyanii okruzhayuschcei sredy v gorode Moskva v 2012 godu [Report for environmental condition in Moscow for year 2012]. Moscow government, department of nature management and environmental protection, Moscow, 2013.

[6] Moscow agency for ecological monitoring. http://www.mosecom.ru/water/quality/

[7] Federal Centre for analysis and evaluation of the technogenic impact. www.fcao.ru

[8] Obzor sostoyaniya i zagryazneniya okruzhayuschcey sredy v Rossiiskoi Federatsii za 2011 god [A review of condition and pollution of environment in Russian Federation for year 2011]. The Federal Service for Hydrometeorology and Environmental Monitoring, Roshydromet, 2012.

[9] Draft agreement on CEMP Assessment Criteria for the QSR 2010. Meeting of the Environmental Assessment and Monitoring Committee (ASMO), Bonn: 20-24 April 2009ASMO 09/7/3-E.

[10] InternationalAgency forResearchinCancer(IARC).doi:http://dx.doi.org/10.1002/0470011815. $\underline{\mathrm{b} 2 \mathrm{a} 17071}$

[11] Ivan Holoubek, Josef Č́áslavaský, Jan Helešic, Roman Vančura, Jirí Kohoutek, Anton Kočan, Ján Petrik \& Jana Chovancová, Project tocoen: the fate of selected organic pollutants in the environment part XXI. The contents of PAHs, PCBs, PCDDs/Fs in sediments from Danube river catchment area. Toxicological \& Environmental Chemistry, 43(3-4), pp. 203-215, 1994. doi: http://dx.doi.org/10.1080/02772249409358032 
[12] Carole Di Giorgio, Wei Liu, Luc Sarrazin, Emmanuel Wafo, Xavier Moreau, Laetitia De Jong, Alain Thiery, Michel De Meo, Organic pollution and genotoxicity of sediments of the Palun marshes (Berre Lagoon, France). Journal of Environmental Quality, 39, pp. 558-567, 2010. doi: http://dx.doi.org/10.2134/jeq2009.0178

[13] Sandro Froehner, Juliandra Zeni, Erissen Cardoso da Luz, Marcell Maceno, Characterization of granulometric and chemical composition of sediments of Barigui River samples and their capacity to retain polycyclic aromatic hydrocarbons. Water, Air and Soil Pollution, 203, pp. 381-389, 2009. doi: http://dx.doi.org/10.1007/s11270-009-0020-1

[14] Charles River sediment/water quality analysis project report. U.S. Environmental Protection Agency, 1996, p. 47. 